\title{
An Endothelial Growth Factor Involved in Rat Renal Development
}

Juan A. Oliver and Qais Al-Awqati

Department of Medicine, Columbia University, College of Physicians \& Surgeons, New York, New York 10032

\begin{abstract}
In the kidney, there is a close and intricate association between epithelial and endothelial cells, suggesting that a complex reciprocal interaction may exist between these two cell types during renal ontogeny. Thus, we examined whether metanephrogenic mesenchymal cells secrete endothelial mitogens. With an endothelial mitogenic assay and sequential chromatography of the proteins in the media conditioned by a cell line of rat metanephrogenic mesenchymal cells (7.1.1 cells), we isolated a protein whose amino acid analysis identified it as hepatoma-derived growth factor (HDGF). Media conditioned with Cos-7 cell transfected with HDGF cDNA stimulated endothelial DNA synthesis. With immunoaffinity purified antipeptide antibodies, we found that HDGF was widely distributed in the renal anlage at early stages of development but soon concentrated at sites of active morphogenesis and, except for some renal tubules, disappeared from the adult kidney. From a 7.1.1 cells cDNA library, a clone of most of the translatable region of HDGF was obtained and used to synthesize digoxigeninlabeled riboprobes. In situ hybridization showed that during kidney development mRNA for HDGF was most abundant at sites of nephron morphogenesis and in ureteric bud cells while in the adult kidney transcripts disappeared except for a small population of distal tubules. Thus, HDGF is an endothelial mitogen that is present in embryonic kidney, and its expression is synchronous with nephrogenesis. (J. Clin. Invest. 1998. 102:1208-1219.) Key words: glomerulogenesis • angiogenesis - glomerular capillary - glomerular growth • hepatomas derived growth factor
\end{abstract}

\section{Introduction}

Development of an organ requires that morphogenesis of its parenchymal cells be synchronized with proliferation, migration, and morphogenesis of the endothelial cells of its vasculature. Anatomical examination of mature organs illustrates the complexity of this process. For example, in the kidney-the organ with the highest blood flow per unit mass in the bodythere are three morphologically and functionally distinct capillary beds (glomerular, peritubular, and vasa recta) each in

Address correspondence to Juan Oliver, M.D., Columbia University, Department of Medicine, 630 West 168th Street, New York, NY 10032. Phone: 212-305-1890; FAX: 212-305-3475; E-mail: jao7@columbia.edu

Received for publication 3 June 1997 and accepted in revised form 30 June 1998.

J. Clin. Invest.

(C) The American Society for Clinical Investigation, Inc. 0021-9738/98/09/1208/12 \$2.00

Volume 102, Number 6, September 1998, 1208-1219

http://www.jci.org close contact with, and functionally linked to, a different nephron segment. An additional level of complexity arises from the fact that each nephron possesses its own vascular supply requiring that morphogenesis of its parenchymal and vascular components occur simultaneously. Each nephron is derived from a single terminal branch of a ureteric bud (an "ampulla"), which induces a group of metanephric mesenchymal cells to form the epithelial cells of the proximal part of the nephron (1). We (2) and others $(3,4)$ have found that as the ureteric bud generates new branches, each of these ampullae become tightly surrounded by endothelial cells, thereby providing a potential targeting mechanism for the vascularization of individual nephrons. This suggests that cells of the renal anlage might synthesize molecules regulating endothelial cell migration and location. Indeed, with monoclonal antibodies, we found an antigen synthesized by embryonic kidney parenchymal cells that collocates with migrating endothelial cells (2). This antigen likely provides embryonic renal endothelial cells with directional cues since addition of the antibody to developing kidney rudiments in vitro inhibited localization of these cells around ureteric bud ampulla (2).

Renal embryonic parenchymal cells also synthesize endothelial growth and chemotactic factors as well as molecules capable of regulating their phenotype. Some epithelial cells of the renal anlage synthesize vascular endothelial growth factor/ vascular permeability factor (VEGF; 5), ${ }^{1}$ a very restrictive endothelial mitogen. Furthermore, while synthesis of VEGF markedly decreases as the kidney matures, synthesis continues in the glomerular epithelial cells of the adult kidney, likely contributing to the high permeability of the glomerular capillary (5-7).

In summary, the intricate arrangement between endothelial and epithelial cells in the adult kidney makes it likely that during its development there exists a complex reciprocal interaction between these two cell types. Accordingly, we postulated that embryonic renal parenchymal cells might secrete endothelial growth and chemotactic factors. We examined this hypothesis by using a cell line isolated from metanephrogenic mesenchymal cells (7.1.1 cells) at day 13 of embryonic age $\left(E_{13}\right)$. These cells have mesenchymal and epithelial markers (8) suggesting that they are mesenchymal cells transforming into epithelia, a process that occurs in the renal anlage at a time of dramatic endothelial growth and migration $(1,2,9)$. We found that media conditioned with 7.1.1 cells contained endothelial chemotactic and growth activity. With an endothelial mitogenic assay and sequential chromatography of serumfree 7.1.1 cells-conditioned media, we isolated a protein whose amino acid sequence was identical to a recently cloned molecule derived from human hepatoma cells and named hepatomaderived growth factor (HDGF; 10).

1. Abbreviations used in this paper: DEPC, diethyl pyrocarbonate, HDGF, hepatoma-derived growth factor; HMG-1, high mobility group 1 protein; PBS C/M, PBS with calcium and magnesium; VEGF, vascular endothelial growth factor. 


\section{Methods}

Cell culture. The metanephrogenic mesenchymal cell line (7.1.1) has been reported (8). Bovine aortic endothelial cells were isolated and maintained as described (11). Rat aortic endothelial cells were isolated as described (12).

Cell growth assay. Growth stimulation activity was assayed by $\left[{ }^{3} \mathrm{H}\right]$ thymidine incorporation into bovine or rat (where noted) aortic endothelial cells. In brief, $10^{4}-10^{5}$ cells were seeded in each well of a 24-well plate (GIBCO BRL, Gaithersburg, MD) and the next day were placed in MEM containing $0.5 \%$ FCS. $24-48 \mathrm{~h}$ later, the fractions to be tested were added to the cells in triplicate. After $18 \mathrm{~h}$, the wells were rinsed with MEM, and $0.5-1.0 \mu \mathrm{Ci} /$ well of $\left[{ }^{3} \mathrm{H}\right]$ thymidine in MEM was added for 2-6 $\mathrm{h}$. Incubation was ended by rinsing with ice-cold PBS and incubating the cells with $10 \%$ TCA at $4^{\circ} \mathrm{C}$. After washing the wells with 1:3 ethanol:chloroform (vol:vol), they were incubated with $200 \mu \mathrm{l}$ of $0.4 \mathrm{~N} \mathrm{NaOH}$ at $60^{\circ} \mathrm{C}$, and after neutralizing with $200 \mu$ l of glacial acetic acid, the samples were mixed with liquid scintillation fluid and counted.

Endothelial cell growth activity of the 7.1.1 cells-conditioned media was also assayed by determining the effect of the media on cell number. In brief, $3 \times 10^{4}$ bovine aortic endothelial cells in MEM with $10 \%$ FCS were seeded in 24-well plates, and $1 \mathrm{~d}$ later, the medium was changed to MEM containing $0.5 \%$ FCS. The next day, $10-100 \mu \mathrm{l}$ of 7.1.1-conditioned media concentrated $\sim 15$-fold (or the same volumes of MEM) were added to wells in triplicate. $5 \mathrm{~d}$ later, cells were trypsinized and counted in Trypan blue.

Isolation of HDGF. Confluent 7.1.1 cells growing in $150-\mathrm{cm}^{2}$ flasks were rinsed twice with MEM (GIBCO) and incubated at $31^{\circ} \mathrm{C}$ with MEM containing penicillin $(60 \mathrm{U} / \mathrm{ml})$, streptomycin $(60 \mathrm{U} / \mathrm{ml})$, and an additional $2 \mathrm{mM} \mathrm{L}$-glutamine (all from GIBCO). 3-6 d later, the media was harvested, centrifuged at $100 \mathrm{~g}$, and the supernatant was passed through a $0.22-\mu \mathrm{m}$ filter and stored at $-20^{\circ} \mathrm{C}$ until used. Before chromatography, the supernatant was concentrated $\sim 15$-fold with a PM10 Amicon membrane (Bedford, MA). The concentrate was equilibrated with $20 \mathrm{mM}$ sodium-phosphate buffer ( $\mathrm{pH} 7.0)$ by gel filtration chromatography (Sephadex G-25; Pharmacia, Piscataway, NJ), and the sample was then applied into a heparin-Sepharose column (Pharmacia), which was eluted with a gradient of $0-1 \mathrm{M} \mathrm{NaCl}$ in the same buffer. The active fractions eluting at $1 \mathrm{M} \mathrm{NaCl}$ were equilibrated with $20 \mathrm{mM}$ MES buffer ( $\mathrm{pH}$ 6.0), applied to a cation exchange column (Resource-S; Pharmacia), and eluted with a $0-0.5 \mathrm{M}$ $\mathrm{NaCl}$ linear gradient. Active fractions (eluting at $0.2 \mathrm{M} \mathrm{NaCl}$ ) were equilibrated with $20 \mathrm{mM}$ sodium phosphate buffer ( $\mathrm{pH}$ 7.2) containing $1 \mathrm{M} \mathrm{NaCl}$ and loaded into a hydrophobic interaction chromatography column (Phenyl-Superose; Pharmacia), which was eluted with a 1-0 $\mathrm{M} \mathrm{NaCl}$ linear gradient. The fractions with endothelial growth activity were mixed with $3 \times$ volumes of acetone at $-20^{\circ} \mathrm{C}$ and incubated for $18 \mathrm{~h}$ at $-20^{\circ} \mathrm{C}$. After centrifugation of the sample, the supernatant was aspirated, and the protein pellet was dried under $\mathrm{N}_{2}$. The pellet was dissolved in $50 \mu \mathrm{l}$ of $0.5 \mathrm{M}$ sodium phosphate buffer ( $\mathrm{pH}$ 7.0) and radiolabeled with ${ }^{125} \mathrm{I}$ with the chloramine $\mathrm{T}$ method (13). Separation of the bound from the free ${ }^{125} \mathrm{I}$ was done by Sephadex G-15 chromatography. The fractions with radiolabeled protein were precipitated with acetone as described above and dissolved in SDS/PAGE sample buffer. SDS/PAGE was performed as described (14).

For amino acid sequence of the isolated protein, the active fractions eluting at $0.2 \mathrm{M} \mathrm{NaCl}$ from the cation-exchange chromatography (see Results) were precipitated with $10 \%$ TCA and subjected to $10 \%$ SDS/PAGE. The band of $14 \mathrm{kD}$ protein was cut from the gel and digested with endoproteinase LysC. The resulting peptides were separated in a Vydac C18 HPLC column (Waters Corp., Milford, MA), and two peptides were sequenced on an Applied Biosystems sequencer (Applied Biosystems, Foster City, CA).

Homogenization of 7.1.1 cells and embryonic kidneys. After extensive washing with ice-cold PBS, confluent 7.1.1 cells were scraped from flasks at $4^{\circ} \mathrm{C}$ into $3 \mathrm{ml}$ of $0.25 \mathrm{M}$ sucrose, $1 \mathrm{mM}$ EDTA, $10 \mathrm{mM}$ imidazole ( $\mathrm{pH}$ 7.0) containing aprotinin, leupeptin, pepstatin (all 1 $\mu \mathrm{g} / \mathrm{ml}$ ), and $100 \mu \mathrm{g} / \mathrm{ml}$ PMSF. Cells were homogenized in a handheld Dounce homogenizer and centrifuged at 5,000 rpm for $5 \mathrm{~min}$ to remove nuclei and unbroken cells. To separate soluble from membrane fractions, the supernatant was next centrifuged at $100 \mathrm{~K} g$ for $1 \mathrm{~h}$. Homogenization of $30 \mathrm{E}_{15}$ kidneys (vaginal plug $=0$ ) was done in $1 \mathrm{ml}$ of the homogenization buffer as described above with two 5-s pulses of a Branson Sonifier followed by centrifugation.

Antibody to HDGF. A fragment of one of the two sequenced peptides (EGLWEIENNPT) was synthesized with a cysteine at its amino terminal, coupled to maleimide-activated KLH (Pierce Chemical Co., Rockford, IL), and injected into rabbits with standard procedures. The presence of antibodies was detected by ELISA by using maleimide-activated bovine serum albumin (Pierce Chemical Co.) coupled to peptide. For immunoaffinity purification of the antibody, maleimide-activated ovalbumin (Pierce Chemical Co.) was first coupled to the peptide and then to a NHS-activated agarose column (Pharmacia). The rabbit antisera was injected into the column, and elution of the antibody was performed as described (15). The eluted antibody was concentrated with a PM10 Amicon membrane and extensively dialyzed versus PBS containing $0.9 \mathrm{mM} \mathrm{CaCl}$ and $1 \mathrm{mM}$ $\mathrm{Mg}_{2} \mathrm{SO}_{4}$ (PBS C/M).

Immunoblots. After SDS/PAGE, the proteins in the gel were transferred into Immobilon-NC transfer membranes (Millipore, Bedford, MA) with a transfer apparatus at $100 \mathrm{mV}$ for $2 \mathrm{~h}$. Immunodetection was done by incubating the membrane with $0.1 \mu \mathrm{g} / \mathrm{ml}$ of immunopurified antibody for $2 \mathrm{~h}$ at $22^{\circ} \mathrm{C}$ in $0.2 \mathrm{M} \mathrm{NaCl}, 50 \mathrm{mM}$ Tris, $\mathrm{pH} 7.5$ containing $0.1 \%$ Tween 20 and $1 \%$ dry milk. After extensive washing, the secondary antibody (Donkey anti-rabbit conjugate to peroxidase; Jackson ImmunoResearch Labs., West Grove, PA) was incubated in identical buffer. After washing, the blot was developed by ECL (Amersham Life Sciences, Buckinghamshire, England).

Transfection of Cos-7 cells with HDGF cDNA. HDGF cDNA was constructed by one of two methods. In one method, PCR with Pfu DNA polymerase (Stratagene, La Jolla, CA) was performed with primers 5'-C.CCC.GCC.ATG.TCG.CGA.TCC.AAC.CGG.CAG. AAG.GAG.TAC-3' (sense nucleotides 309-345) and 5'-GGT.TCC. CAG.TTT.GCA.GGC.CAT.GG-3' (antisense nucleotides 1107-1129) containing, respectively, EcoRI and XhoI restriction sites. Analysis of the nucleotide sequence of the isolated product confirmed its identity as the cDNA for HDGF (not shown). After digestion with these enzymes, the PCR product was ligated into vector pCDNA3.1 (Invitrogen, Carlsbad, CA) and used to tranform Epicurian Coli XL1Blue supercompetent cells (Stratagene). In the second method, a 7.1.1 cDNA library constructed from poly $(\mathrm{A})^{+}$mRNA from 7.1.1 cells (Invitrogen) was screened with a digoxigenin-labeled probe generated by PCR (Boehringer Mannheim, Indianapolis, IN) with the primers described above. Three positive clones were isolated, but none included the $5^{\prime}$ end of the HDGF cDNA. Accordingly, the clone containing the stop codon (with nucleotides 712-1080 of the HDGF cDNA) was digested with XhoI and MaeII and ligated with a fragment of the PCR product described above after its digestion with EcoRI and MaeII (nucleotides 309-816 of HDGF cDNA). The resulting product was inserted into the pCDNA3.1 vector.

Monkey Cos-7 cells $\left(0.5 \times 10^{6}\right)$ were seeded on plates $(100 \mathrm{~m}$ diameter) the day before transfection. Transfection was carried out with $15 \mu \mathrm{g}$ of plasmid DNA with the calcium chloride method (Promega, Madison, WI). Transfections were done in parallel with the pCDNA3.1 vector and the vector containing the cDNA of HDGF.

Immunohistochemistry. Embryonic kidneys were isolated and processed as described (2). Immunostaining with HDGF antibodies was done by incubating 4-6- $\mu \mathrm{m}$ sections with $50 \mathrm{mM} \mathrm{NH}_{4} \mathrm{Cl}$ followed by 10 -min incubation with PBS C/M containing $0.1 \%$ Triton $\times 100$. Antibody $(10 \mu \mathrm{g} / \mathrm{ml})$ was next added in PBS C/M containing $1 \%$ bovine serum albumin for $2 \mathrm{~h}$. After extensive washing with PBS C/M containing $2.7 \% \mathrm{NaCl}$ and $0.05 \%$ Tween 20 , FITC or rhodamine-coupled goat anti-rabbit antibody (Jackson ImmunoResearch) in PBS C/M 
with $4 \%$ rat serum and $4 \%$ goat serum was incubated for $1 \mathrm{~h}$. After washing, sections were mounted and examined with a fluorescence microscope. Control slides by incubating the primary antibody in the presence of a 100 -fold molar excess of the peptide used to generate the antibody gave no signal.

Reverse transcription PCR for HDGF. RNA from 7.1.1 cells was isolated with RNAzol (Tel-Test Inc., Friendswood, TX). $15 \mu \mathrm{g}$ of total RNA were reverse transcribed with random examers with the GeneAmp PCR kit (Perkin Elmer, Norwalk, CT). PCR was then performed using primers derived from the human cDNA (13): 5'-AAC.CGG.CAG.AAG.GAG.TAC.AAA.TGC-3' (sense nucleotides 328-351) and 5'-GTT.CCC.AGT.TTG.CAG.GCC.ATG.G-3' (antisense nucleotides 1107-1128).

$P C R$ for HDGF in cDNA libraries of 7.1.1 cells and of $E_{14}$ rat kidneys. The rat $\mathrm{E}_{14}$ embryonic kidney cDNA library was a gift of Jonathan Barasch (Columbia University, New York, NY). Plasmids were purified as instructed in the QIAprep Spin Kit (QIAGEN, Valencia, CA). $500 \mathrm{ng}$ of plasmid DNA were PCR with the GeneAmp PCR Reagent kit (Perkin Elmer) with the two primers described above. Nested PCR was performed with the product obtained with the two initial primers and the following internal primers: 5'-TTT. TTC.GGG.ACC.CAC.GAG.AC-3' (sense nucleotides 460-479); 5'-TTC.TTC.TCC.TTG.GCT.GGC.TC-3' (antisense nucleotides 742761); 5'-TTC.TGC.CTC.CTT.GGG.ACG.TTT-3' (antisense nucleotides 814-834).

Preparation of RNA probes and Northern blotting. The 801-bp PCR product obtained from the 7.1.1 cells cDNA library was ligated into vector pCR II (Invitrogen) and cloned. The plasmid was linearized with EcoRV and BamHI, and sense and antisense RNA labeled with digoxigenin were synthesized with the DIG RNA labeling kit (Boehringer Mannheim). After measuring their concentration by serial dilutions on a nylon membrane, the probes were purified by precipitation with $4 \mathrm{M} \mathrm{LiCl}$ and ethanol washed (16).

The antisense probe was first tested in Northern blot hybridization with polyadenylated RNA from 7.1.1 cells. In brief, total RNA from 7.1.1 cells obtained as described above was incubated with Oligotext beads (QIAGEN), and polyadenylated RNA was isolated. 10 $\mu \mathrm{g}$ of $\operatorname{poly}(\mathrm{A})^{+}$RNA were subjected to electrophoresis in a $1 \%$ agarose gel containing formaldehyde as described (16) and transferred onto Nytran nylon membrane (Schleicher \& Schuell, Keene, NH). Hybridization was performed as described (16) with the antisense probe synthesized above, and chemiluminescent detection was performed with the Genius 7 Luminescent Detection Kit (Boehringer Mannheim).

In situ hybridization. 7.1 .1 cells were washed with $0.1 \%$ DEPCtreated PBS and suspended by incubating them with PBS containing $0.2 \%$ EDTA. Except when incompatible, such as the presence of Tris, all solutions were treated with $0.1 \%$ diethyl pyrocarbonate (DEPC). $10^{5}$ cells in $100 \mu \mathrm{l}$ were cytospun onto baked slides (ETHO cleaned, DEPC $-\mathrm{H}_{2} \mathrm{O}$ rinsed), allowed to dry and fixed in 3\% paraformaldehyde in DEPC-treated PBS for $1 \mathrm{~h}$ at room temperature. After rinsing with PBS, slides with the cells were placed in $70 \%$ ethanol and progressively dehydrated with ethanol $(85 \%, 100 \%)$ and xylene. Thereafter, they were processed as the tissue sections (see below).

Kidneys were microdissected and placed in $4 \%$ paraformaldehyde in PBS for $18 \mathrm{~h}$ at $4^{\circ} \mathrm{C}$. After rinsing three times with PBS, they were placed into $70 \%$ ethanol. They were embedded in paraffin according to standard procedures. Sections of $4 \mu \mathrm{m}$ were cut, and after drying the slides overnight at $50^{\circ} \mathrm{C}$, they were dewaxed with xylene and rehydrated with sequential incubations with ethanol $(100 \%, 95 \%, 70 \%$, and $50 \%$ ) and finally with $\mathrm{H}_{2} \mathrm{O}$. Before hybridization, the slides were subjected to the following treatments: incubation with $0.2 \mathrm{~N} \mathrm{HCl}$ for 5 min; rinsed with $\mathrm{H}_{2} \mathrm{O}$; incubation with $10 \mu \mathrm{g} / \mathrm{ml}$ proteinase $\mathrm{K}$ (Boehringer Mannheim) in $50 \mathrm{mM}$ EDTA, $100 \mathrm{mM}$ Tris (pH 8.0) for $15 \mathrm{~min}$ at $22^{\circ} \mathrm{C}$; rinsed with PBS; fixation with $4 \%$ paraformaldehyde in PBS for $10 \mathrm{~min}$; rinsed with PBS; acetylation with $0.5 \%$ acetic anhydride in $0.1 \mathrm{M}$ triethanolamine $(\mathrm{pH} 8.0)$ at $22^{\circ} \mathrm{C}$ for $15 \mathrm{~min}$, and twice rinsed with SSC $(0.15 \mathrm{M} \mathrm{NaCl} ; 15 \mathrm{mM}$ sodium citrate, $\mathrm{pH}$ 7.0). The hybrid-
Table I. ${ }^{3} \mathrm{H}$-Thymidine Incorporation into Endothelial Cells Induced by 7.1.1 Cells-Conditioned Media

\begin{tabular}{lc}
\hline Cell & $\%$ above control \\
\hline BAEC & $57 \pm 6$ \\
RAEC & $46 \pm 11$
\end{tabular}

BAEC and RAEC, bovine and rat aortic endothelial cells. Mean \pm SE. $n=5$ for each cell type with each experiment being the average of three wells.

ization mixture contained either of the digoxigenin-labeled RNA probes $(100 \mathrm{ng} / \mathrm{ml}), 50 \%$ deionized formamide (Fisher Scientific Co., Pittsburgh, PA), $4 \times$ SCC, $1 \times$ Denhardt's solution (Sigma Chemical Co., St. Louis, MO), $0.5 \mathrm{mg} / \mathrm{ml}$ of heat-denatured herring sperm DNA (Sigma Chemical Co.), $25 \mathrm{mg} / \mathrm{ml}$ yeast tRNA (Sigma Chemical Co.), and 10\% dextran sulfate (Oncor Inc., Gaithersburg, MD). The slides were incubated with the probes at $50^{\circ} \mathrm{C}$ for $\sim 20 \mathrm{~h}$ after which they were subjected to the following treatments: twice washed with $2 \times$ SSC at $42^{\circ} \mathrm{C}$ for $15 \mathrm{~min}$ on a shaker, followed by $2 \mathrm{mM}$ EDTA, $50 \mathrm{mM}$ TRIS (pH 7.5) for $1 \mathrm{~min}$ at $22^{\circ} \mathrm{C}$. To remove unhybridized probe the slides were next treated with $5 \mu \mathrm{g} / \mathrm{ml}$ of RNase T (Boehringer Mannheim) in the previous solution for $30 \mathrm{~min}$ at $37^{\circ} \mathrm{C}$. After the RNase treatment, the slides were washed as follows: $2 \times$ SCC with $50 \%$ formamide for $10 \mathrm{~min}$ at $42^{\circ} \mathrm{C}$ followed by $0.2 \times \mathrm{SCC}$ for $20 \mathrm{~min}$ at $42^{\circ} \mathrm{C}$ and finally $0.1 \times \mathrm{SSC}$ for $15 \mathrm{~min}$ at $42^{\circ} \mathrm{C}$.

Immunological detection was done with the DIG nucleic acid detection kit (Boehringer Mannheim). For each incubation with the antisense riboprobe, a section of the same embryonic age was incubated with the sense riboprobe. Additional negative controls included slides pretreated with $5 \mu \mathrm{g} / \mathrm{ml}$ RNase T before hybridization and slides processed in the absence of riboprobe.

\section{Results}

Endothelial growth activity of 7.1.1 cells-conditioned media. In initial studies, we examined whether 7.1.1 cells-conditioned media had mitogenic activity for endothelial cells. As shown in Table I, $50 \mu \mathrm{l}$ of a 15-fold concentrate of 7.1.1 cells-conditioned media increased $\left[{ }^{3} \mathrm{H}\right]$ thymidine incorporation into bovine and rat aortic endothelial cells. Moreover, as shown in Table II, increasing volumes of conditioned media progressively increased the cell number of growth arrested bovine aortic endothelial cells.

Purification of HDGF from 7.1.1 cells-conditioned media. To isolate endothelial mitogens secreted by the 7.1.1 cells, the proteins in the media conditioned by the cells were subjected to sequential chromatography while the endothelial mitogenic activity was assayed by $\left[{ }^{3} \mathrm{H}\right]$ thymidine incorporation into bo-

Table II. Effect of 7.1.1 Cells-Conditioned Media on Endothelial Cell Number

\begin{tabular}{rccc}
\hline & \multicolumn{2}{c}{ Cell number $\left(\times 10^{4}\right)$} & \\
\cline { 2 - 3 } Volume & Control & Conditioned media & $\Delta$ \\
\hline $10 \mu \mathrm{l}$ & $2.5 \pm 0.7$ & $2.9 \pm 0.4$ & 0.4 \\
$50 \mu \mathrm{l}$ & $2.5 \pm 0.6$ & $8.8 \pm 1.3$ & $6.3^{*}$ \\
$100 \mu \mathrm{l}$ & $2.5 \pm 0.4$ & $9.1 \pm 1.3$ & $6.6^{*}$ \\
\hline
\end{tabular}

Mean \pm SE; $n=4$ with each experiment being the average of three wells. $* P<0.01$ 
A

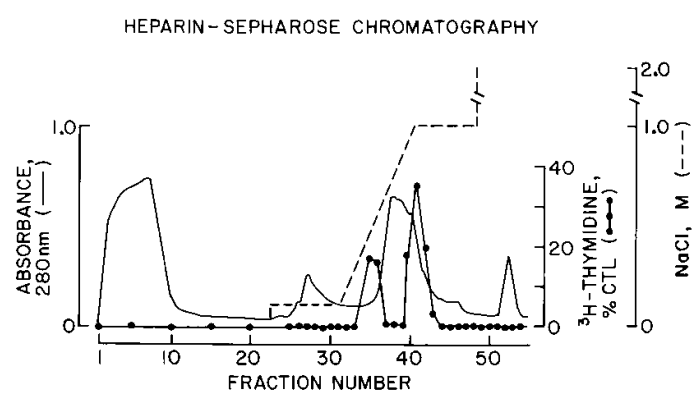

B

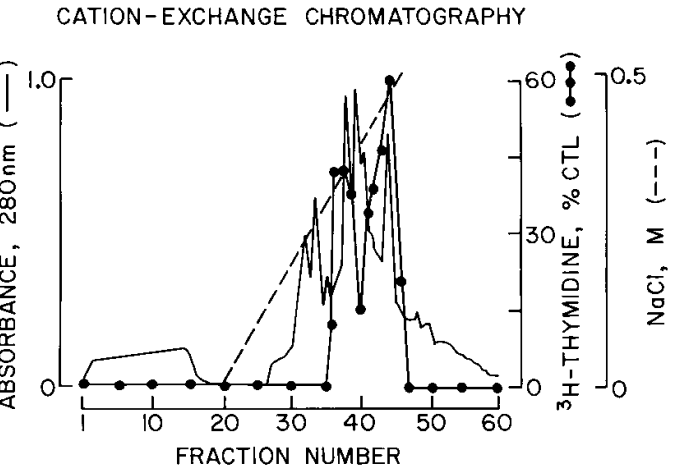

C HYDROPHOBIC INTERACTION CHROMATOGRAPHY



Figure 1. Chromatographic profiles and endothelial mitogenic activity of 7.1.1 cells-conditioned media eluted from heparin-Sepharose $(A)$, cation exchange $(B)$, and hydrophobic interaction $(C)$ columns. All elutions were carried out in an FPLC (Pharmacia). Each fraction was assayed in triplicate for $\left[{ }^{3} \mathrm{H}\right]$ thymidine incorporation into bovine aortic endothelial cells. The peak of activity eluting at $1 \mathrm{M} \mathrm{NaCl}$ from heparin-Sepharose was injected into the cation-exchange column. The peak of activity eluting from this column at $0.2 \mathrm{M} \mathrm{NaCl}$ was injected into the hydrophobic interaction column.

vine aortic endothelial cells. First, 7.1.1 cells-conditioned media were applied to a heparin-Sepharose column (Fig. 1A) and eluted with increasing concentration of $\mathrm{NaCl}$. Two peaks of $\left[{ }^{3} \mathrm{H}\right]$ thymidine incorporation activity eluted from the column and the peak eluting at $1 \mathrm{M} \mathrm{NaCl}$ (second peak of activity in Fig. $1 A$ ) was injected into a cation exchange chromatography column. Two peaks of activity eluted (at $0.2 \mathrm{M}$ and $0.4 \mathrm{M}$ $\mathrm{NaCl}$ ) from this column (Fig. $1 B$ ) and the first peak (fractions
A $\quad B$

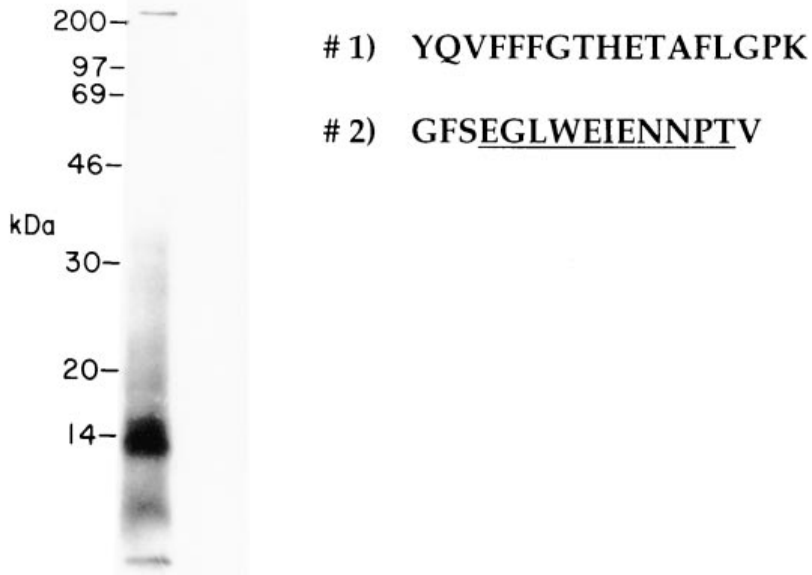

Figure 2. SDS/PAGE analysis $(A)$ and partial amino acid sequence $(B)$ of the endothelial mitogen purified from 7.1.1 cells-conditioned media. $(A)$ The proteins in the active fraction eluting from the hydrophobic interaction column (Fig. $1 C$ ) were radiolabeled and subjected to $5-15 \%$ gradient SDS/PAGE under reducing conditions. After drying, gel visualization was done by autoradiography. $(B)$ Amino acid sequence of two proteolytic peptides from the purified protein. The underline fragment of peptide 2 was used to obtain antibodies.

38 and 39) was processed further. The endothelial growth activity in these fractions showed a high degree of hydrophobicity and, unlike most other proteins in the sample, bound to the hydrophobic interaction column at low salt concentration (1 M $\mathrm{NaCl}$ ). As shown in Fig. $1 C$, a single peak of endothelial growth activity eluted from the hydrophobic interaction column. Radio-iodination of the proteins present in this peak revealed a prominent band with an apparent molecular mass of $\sim 14 \mathrm{kD}$ in SDS/PAGE (Fig. $2 A$ ). Because only limited amounts of active protein could be prepared from the hydrophobic interaction column, the active fractions eluting at $0.2 \mathrm{M}$ $\mathrm{NaCl}$ from the cation exchange column (37 and 38 in Fig. $1 B$ ) were subjected to SDS/PAGE, and after staining with Coomassie brilliant blue, the $14-\mathrm{kD}$ band was excised from the gel and processed for protein sequencing as described in Methods. The sequences of two proteolytic fragments (Fig. $2 \mathrm{~B}$ ) were identical to amino acids 45-61 and 81-95 of the recently identified human HDGF (10).

Immunodetection of HDGF in 7.1.1 cells and embryonic kidney. Two polyclonal rabbit antibodies were generated from a fragment (EGLWETENNPT) of peptide 2 (underlined in Fig. $2 \mathrm{~B}$ ) and used for immunodetection of HDGF. 7.1.1 cell homogenates immunoblotted with immunopurified antibody (Fig. 3) showed an $\sim 40-\mathrm{kD}$ band (7.1.1 cells lane). As shown in Fig. 3, an identical band was also detected in homogenates of rat $\mathrm{E}_{15}$ kidney, indicating that HDGF is present in developing kidney. In serum-free 7.1.1 cells-conditioned media harvested after $3 \mathrm{~d}$ of incubation (Fig. 3, 3 days lane), the same $\sim 40-\mathrm{kDa}$ band was also detected. However, as shown in Fig. 3 , an additional band of $\sim 25 \mathrm{kDa}$ and a less prominent band of $\sim 35 \mathrm{kDa}$ were also detected by the antibody. Furthermore, if conditioned media were harvested after more than $3 \mathrm{~d}$ of 

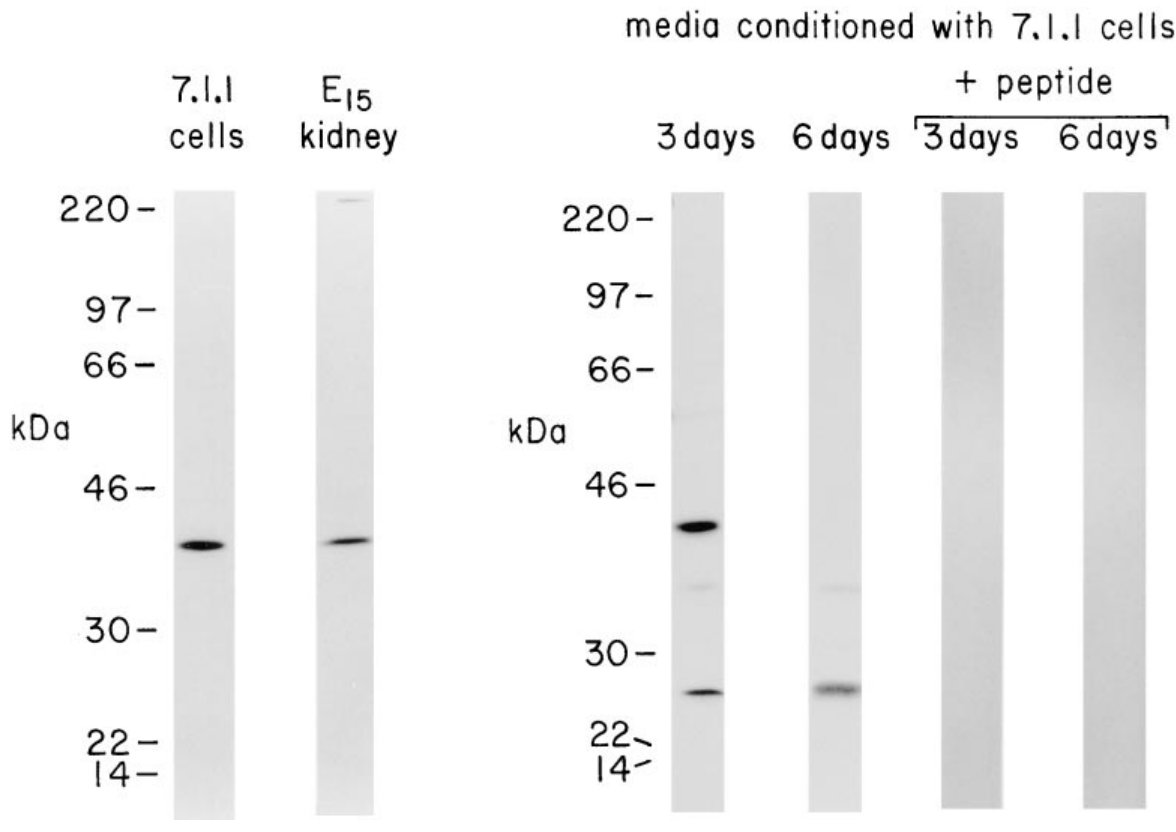

\begin{abstract}
Figure 3. Immunoblots with immunopurified antibody to HDGF. 7.1.1 cell homogenates (100 $\mu \mathrm{g}$ protein) and rat $\mathrm{E}_{15}$ kidney homogenates (100 $\mu \mathrm{g}$ protein). The 7.1.1 cell-conditioned media were harvested after $3 \mathrm{~d}$ of culture in serum-free media $(3 \mathrm{~d}$; $50 \mu \mathrm{g}$ protein) or after $6 \mathrm{~d}(50 \mu \mathrm{g}$ protein). Immunoblots were also performed in the presence of the peptide $(100 \times$ antibody concentration) used to raise the antibody.
\end{abstract}

culture ( 6 days lane), the $\sim 40-\mathrm{kD}$ band disappeared, and only the prominent $\sim 25-\mathrm{kD}$ and faint $\sim 35$-kD bands could be detected. When the peptide used to generate the antibodies was added to the antibody during its incubation with the immunoblot ( + peptide lanes), neither the $\sim 40$ - nor the $\sim 25-\mathrm{kD}$ bands were detected (Fig. 3).

Expression of HDGF cDNA in Cos-7 cells. The media conditioned by Cos-7 cells transfected with either the pCDNA3.1 vector (mock transfection) or the vector containing the cDNA for HDGF were analyzed by immunoblots. As shown in Fig. 4 $A$, while no protein was detected by the immunopurified antibody in the conditioned media of the mock-transfected cells, two proteins were apparent in the media from the cells transfected with HDGF cDNA. The most abundant protein had an apparent molecular mass of $\sim 40 \mathrm{kD}$ (identical to that found in media from 7.1.1 cells) while the other was $\sim 35 \mathrm{kD}$. This smaller protein was also present, albeit in small amounts, in the 7.1.1 cells-conditioned media (see Fig. 3).

To test the mitogenic effect of the expressed HDGF, the media conditioned with the mock Cos-7-transfected cells and the media from the cells transfected with HDGF cDNA were injected into heparin-Sepharose columns to isolate the $1.0 \mathrm{M}$ $\mathrm{NaCl}$ fractions. Interestingly, as shown in Fig. $4 \mathrm{~B}$, immunoblots of the sample containing HDGF revealed a new immunoreactive band of $\sim 14 \mathrm{kD}$, the molecular mass of our initially isolated protein (see Fig. $2 A$ ).

Fig. 5 shows the effect on $\left[{ }^{3} \mathrm{H}\right]$ thymidine incorporation into BAEC of the fractions eluting at $1.0 \mathrm{M} \mathrm{NaCl}$ from the heparinSepharose column. Whereas the fractions from the conditioned media of the mock transfection had no effect, those from the media of the cells transfected with HDGF cDNA increased $\left[{ }^{3} \mathrm{H}\right]$ thymidine incorporation. Similar results were obtained with Swiss albino 3T3 cells (not shown; 10).

Immunohistochemistry. Fluorescence immunocytochemistry with affinity-purified rabbit antibodies to HDGF detected this protein in the cytoplasm of all 7.1.1 cells, whereas nuclei showed no signal (Fig. 6). In these cells grown in vitro, staining was most intense in the perinuclear space, with a morphological appearance suggestive of Golgi distribution.

Immunohistochemistry of embryonic kidneys showed that location of HDGF changed markedly during kidney development. Upon arrival of the ureteric bud to the metanephrogenic
A

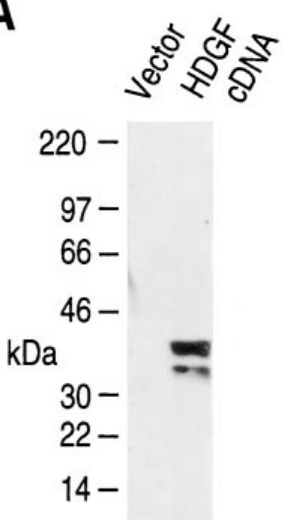

B

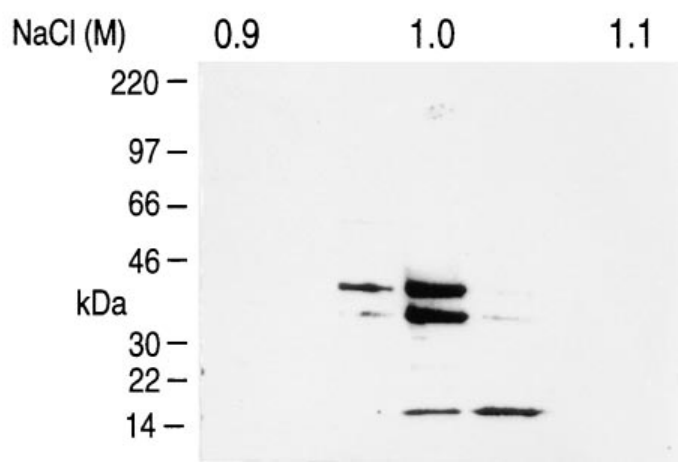

Figure 4. Expression of HDGF cDNA in Cos-7 cells. $(A)$ Immunoblots of media conditioned with mock transfected Cos-7 cells (Vector) and with cells transfected with HDGF cDNA. $100 \mu$ l of conditioned media were subjected to $5-20 \%$ SDS/ PAGE under reducing conditions. (B) Immunoblot of the heparin-Sepharose fractions eluting at $\sim 1.0 \mathrm{M} \mathrm{NaCl}$ from the media conditioned with cells transfected with HDGF cDNA. Chromatography fractions were of $2 \mathrm{ml}$ and $15 \mu \mathrm{l}$ of each fraction were subjected to SDS/PAGE as in $A$. 


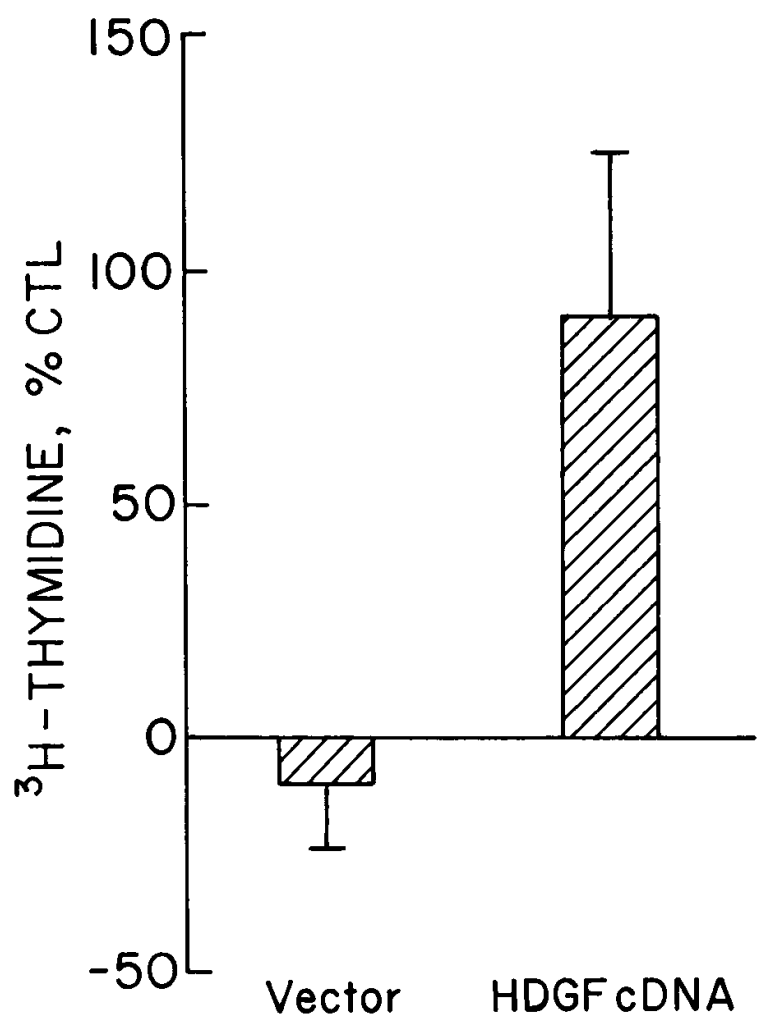

Figure 5. Effect of conditioned media by Cos-7-transfected cells on $\left[{ }^{3} \mathrm{H}\right]$ thymidine incorporation into bovine aortic endothelial cells. The fraction eluting at $1.0 \mathrm{M} \mathrm{NaCl}$ from heparin-Sepharose chromatography of supernatants of Cos-7 cells transfected with HDGF cDNA increased $\left[{ }^{3} \mathrm{H}\right]$ thymidine incorporation, but the same fraction from mocktransfected Cos-7 (vector) did not show activity $(n=3)$. Assuming that the immunoblot signal of HDGF in Fig. $4 B$ represents $\sim 5-20$ $\mathrm{ng}$, the concentration of recombinant protein used in these experiments was $\sim 15-60 \mathrm{ng} / \mathrm{ml}$.

mesenchyme (Fig. $7 A ; \mathrm{E}_{13}$ ) both mesenchymal $(m)$ and ureteric bud $(u b)$ cells contained a strong signal. HDGF was present in most cells during the early stages of kidney development but the signal was particularly prominent in aggregates of mesenchymal cells called "vesicles" ( $v$; Fig. 7 B; $\left.\mathrm{E}_{14}\right)$. As kidney development advanced (Fig. $7 C ; \mathrm{E}_{15}$ ) HDGF preferentially located at sites of epithelial morphogenesis such as "comma" $(c)$ and "s" bodies ( $s)$ as well as the tip of developing nephrons (Fig. $7 D ; \mathrm{E}_{17}$ ), including the glomerular tuft $(g)$. Fig. $7 E\left(\mathrm{E}_{19}\right)$ shows that as glomeruli $(g)$ developed, ureteric bud cell ampullae $(u b)$ remained strongly positive. As glomeruli matured (Fig. $7 F ; \mathrm{E}_{19}$ ), HDGF became less prominent in the glomerular tuft $(g)$ but was easily detectable in the glomerular parietal epithelial cells ( $p e$ ). As shown in Fig. 7, $A-F$, encompassing renal anlages from $\mathrm{E}_{13}$ to $\mathrm{E}_{19}$, during the early and middle periods of renal development, HDGF is characteristically found in the periphery of the cells, at sites of cell-to-cell contact, perhaps suggesting that HDGF acts in a paracrine manner.

As development advanced ( $\left.\mathrm{E}_{20-21}\right)$, HDGF became hardly detectable in the glomerular tuft ( $g$; Fig. $7 G$; $\left.\mathrm{E}_{21}\right)$ but was prominent in some renal tubules. In the adult (Fig. $7 \mathrm{H}$ ), glomeruli $(g)$ had no detectable HDGF, but some renal tubules contained the factor. Most tubules had HDGF in well-defined vesicles and by their morphology could be identified as proximal tubules ( $p t$; Fig. $7 H$ ). Much weaker staining was present in fewer tubules that had a diameter $\sim 28 \mu \mathrm{m}$ and were thus identified as distal tubules $(d t$, Fig. $7 H)$. In contrast with the findings during the early phases of kidney development where HDGF located in areas of cell-to-cell contact, in the later stages of development and in the adult kidney, HDGF location had a vesicular characteristic suggesting that it is either released by a different mechanism or might even be endocytosed into the tubule from the blood stream.

$H D G F$ expression in 7.1.1 cells and $E_{14}$ kidneys. As assessed by RT-PCR, the predicted 801-bp transcript was detected in 7.1.1 cells (Fig. $8 A$, lane 1 ), and its identity was confirmed by the presence of an Xmn I restriction site (lane 2). Furthermore, the appropriate 801-bp product comprising almost all translatable region of HDGF cDNA was also obtained by PCR of a 7.1.1 cDNA library (Fig. $8 \mathrm{~B}$, lane 1 ) and a cDNA library from $\mathrm{E}_{14}$ rat kidneys (Fig. $8 C$, lane 1 ). Identity of these products was established by nested PCR with internal primers (Fig. $8 \mathrm{~B}$, lanes 2 and 3 and Fig. $8 \mathrm{C}$, lane 2). Furthermore, partial sequence of the product obtained with the PCR of the 7.1.1

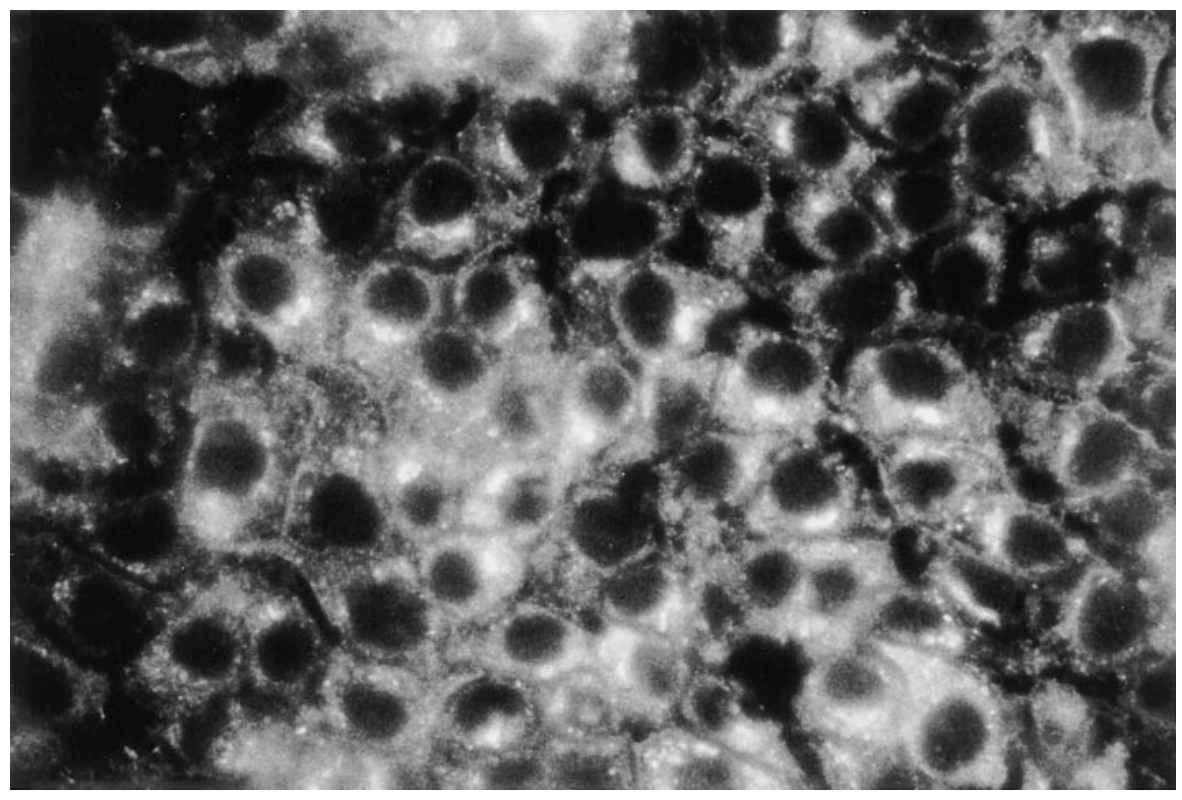

Figure 6. Immunocytochemistry of 7.1.1 cells. 7.1 .1 cells were fixed with $4 \%$ paraformaldehyde and permeabilized with $1 \%$ triton $\times 100$. After incubation with immunopurified antibody, bound antibody was detected with FITC-conjugated anti-rabbit IgG. Control slides with a 100 molar excess of the peptide used to obtain the antibody gave no signal. 


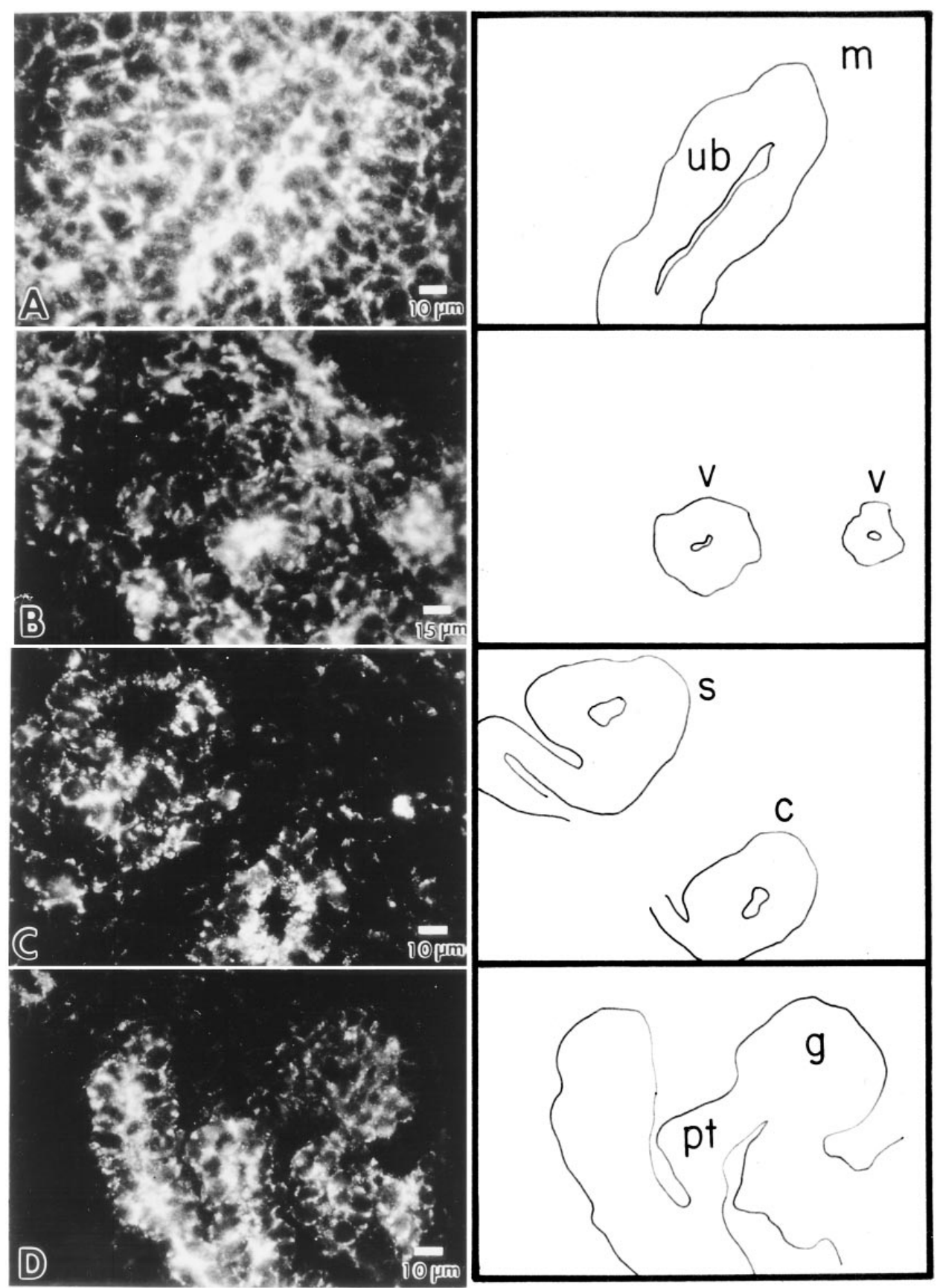

Figure 7. Immunohistochemical analysis of developing kidney with immunopurified antibody to HDGF peptide. $(A) \mathrm{E}_{13}$ renal anlage with ureteric bud $(u b)$ surrounded with metanephrogenic mesenchyme $(m)$. (B) $\mathrm{E}_{14}$ renal anlage showing condensates of mesenchymal cells (vesicles, $v$ ) indicating mesenchymal-epithelial conversion. (C) $\mathrm{E}_{15}$ renal anlage with a comma $(c)$ and $\mathrm{s}$ $(s)$ bodies. $(D)$ Early nephron with glomerular tuft $(g)$ and proximal tubule $(p t)$ at $\mathrm{E}_{17}$. $(E)$ More mature glomerulus $(g)$ and ureteric bud ampulla $(u b)$ at $\mathrm{E}_{19 .}(F)$ Glomerulus $(g)$ in an $\mathrm{E}_{19}$ kidney showing parietal epithelial cells (pe). $(G) \mathrm{E}_{21}$ kidney (date of birth) with a glomerulus $(g)$ and several proximal tubules $(p t)$. $(H)$ Adult kidney with several glomeruli $(g)$, proximal $(p t)$, and distal $(d t)$ tubules. library cDNA confirmed its identity as the cDNA for HDGF (not shown).

In situ hybridization. The riboprobe was first tested in Northern blot hybridization with polyadenylated mRNA from 7.1.1 cells. As shown in Fig. $9 A$ the riboprobe hybridized with a mRNA that is the same size as the mRNA of human HDGF (10). Fig. $9 B$ shows that in situ hybridization of 7.1.1 cells gave a strong signal with the antisense probe (top) and no signal with the sense probe (bottom).

Similarly, the sense probe gave no significant hybridization signal over renal tissue from different embryonic ages (Fig. 10, $C, I, N$, and $Q$ show examples). In early stages of kidney development ( $\left.E_{13-16}\right)$, HDGF transcripts were detected both in the metanephrogenic mesenchyme $(m)$ and ureteric bud $(u b$; Fig.
$10 A$; $\mathrm{E}_{13}$; Fig. $10 B ; \mathrm{E}_{15}$ ) albeit the hybridization signal was weak except in the outer part of the mesenchyme at $\mathrm{E}_{15}$ (Fig. $10 \mathrm{~B})$.

There was a marked increase in the hybridization signal in the middle period of kidney development $\left(\mathrm{E}_{17-19}\right)$. At $\mathrm{E}_{17}$ (Fig. $10, D, E$, and $F$ ), hybridization was particularly strong in cells of the branching ureteric bud ( $u b$, Fig. 10, $D$ and $E$ ) and the mesenchymal interstitial cells while mesenchymal-derived epithelial cells such as those in early "s" bodies ( $s$, Fig. 10, $D$ and $F$ ) had a weaker signal. 2 d later at $\mathrm{E}_{19}$ (Fig. 10, $G$ and $H$ ), hybridization became stronger in "s" bodies ( $s$, Fig. 10, $G$ and $H$ ), but this was transient as glomeruli $(g$, Fig. $10 G)$ that had matured had a weaker signal. A similar pattern persisted for the next $2 \mathrm{~d}$ as shown in $\mathrm{E}_{21}$ (Fig. $10, J$ and $K$ ). Of note is that as 


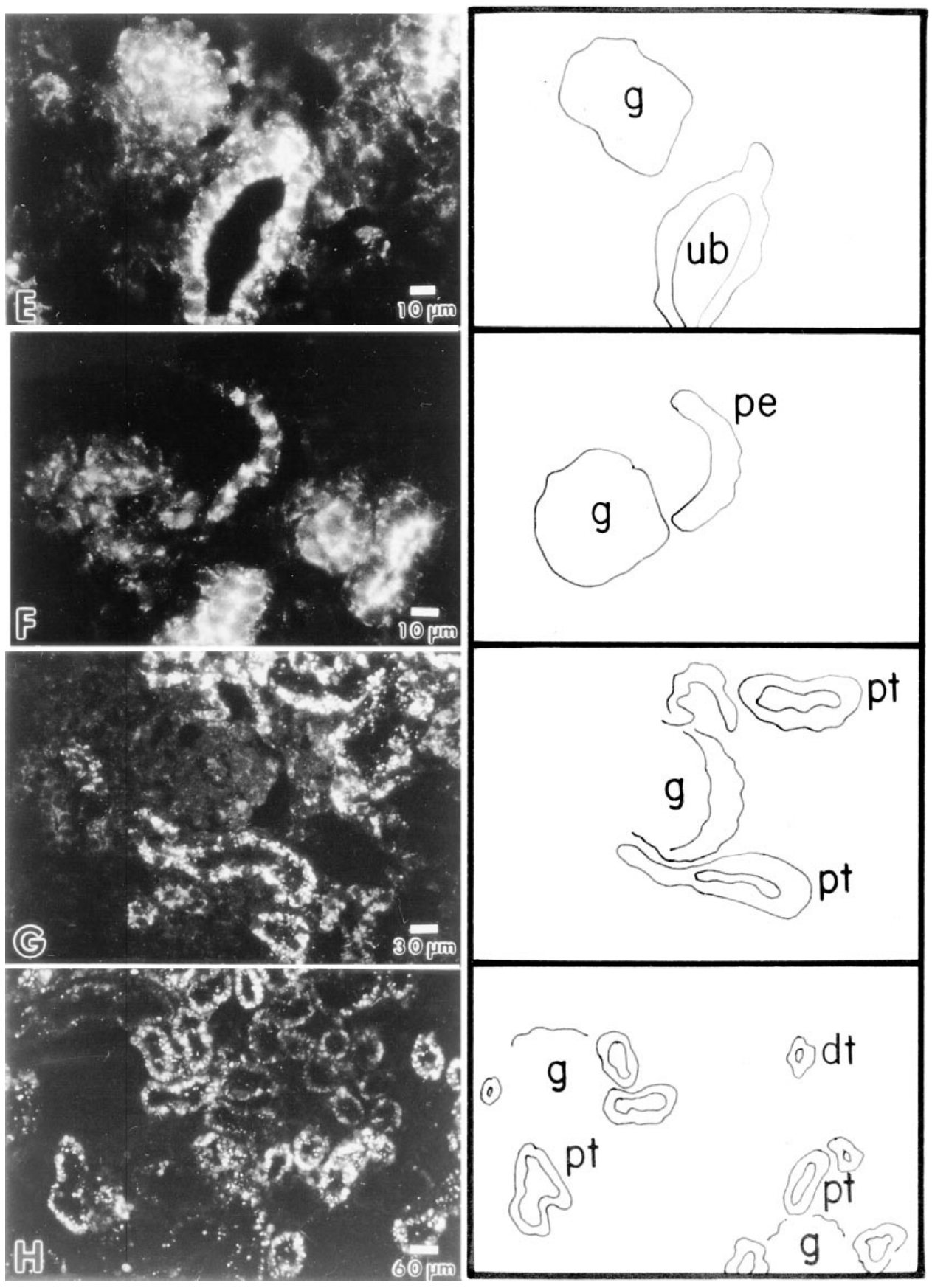

Figure 7 (Continued)

glomerular tuft developed, their hybridization signal became weaker ( $g$, Fig. $10 \mathrm{~K}$ ), but HDGF mRNA expression remained strong in the semicircular cluster of parietal glomerular epithelial cells (pe; Fig. $10 \mathrm{~K}$ ) and in what appeared to be distal tubules.

1 wk after birth (Fig. 10, $L$ and $M$ ), development is completed in the inner part of the kidney, and the hybridization signal there was negative except in tubules that entered the renal medulla, likely collecting ducts. In contrast, there was a weak hybridization signal in the outer cortex $(o c)$ of the kidney where renal development continues in the rat; note embryonic epithelial structures such as "s" bodies ( $s$, Fig. $7 M$ ). In the adult kidney (Fig. 10, $O$ and $P$ ) all glomeruli $(g)$ were negative, and only a small group of renal tubules had a positive hybrid- ization signal. The diameter of these tubules averaged $30 \pm 2$ $\mu \mathrm{m}(n=26)$ and were thus identified as distal tubules ( $d t$, Fig. $7 P$ ), which by their morphological appearance, appeared most likely to be collecting ducts.

\section{Discussion}

When the cells of the renal anlage organize to form mature nephrons they are surrounded by invading and proliferating endothelial cells $(1,2,9)$. Fig. 11 shows a schematic diagram of the initial events in the development of the renal vasculature; endothelial cells invade the metanephrogenic mesenchyme from the ilium and periphery $(A)$ and quickly proliferate throughout the developing kidney, simultaneously with the 
A

RT-PCR

7.1.1 cells

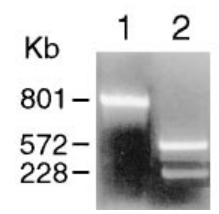

B

PCR 7.1.1 CDNA

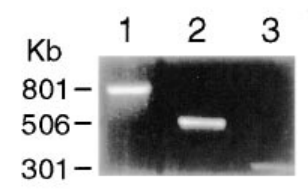

Figure 8. RT-PCR of RNA from 7.1.1 cells $(A)$, PCR of cDNA from 7.1.1 cells $(B)$, and cDNA from $\mathrm{E}_{14}$ rat kidney $(C) .(A)$ RT-PCR appropriate product for HDGF was located at $801 \mathrm{bp}$ (lane 1) and after restriction digestion with Xmn I gave appropriate fragments (lane 2). (B) PCR of 7.1.1 cDNA library amplified an appropriate 801-bp product (lane 1), which when subjected to nested PCR gave expected products (lanes 2 and 3). (C) PCR of $\mathrm{E}_{14}$ rat kidney cDNA also gave an 801-bp product (lane 1), which was used for nested PCR with internal primers (lane 2). condensation and epithelialization of the mesenchymal cells under the influence of the branching ureteric bud $(B)$. As nephron morphogenesis advances, endothelial cells invade the crevice of the "comma" and "s" bodies $(C)$. Morphogenesis and proliferation at these sites leads to development of the glomerular capillary bed in early ( $D$ and $E$ ) and mature glomeruli $(F)$. The close association and parallel morphogenesis of renal parenchymal and endothelial cells makes it likely that a reciprocal interaction exists between these two cell types. With this in mind, we used media conditioned by a line of metanephrogenic mesenchymal cells to isolate an endothelial mitogen. Two proteolytic peptides of the isolated factor had complete identity with two segments of the amino acid sequence predicted from the cDNA of human HDGF (10). Immunoblots using antipeptide antibodies showed that HDGF from 7.1.1 cells and from $\mathrm{E}_{15}$ kidneys had an apparent molecular mass of $\sim 40 \mathrm{kD}$. As the cDNA sequence of human HDGF predicts a protein of 240 amino acids (10), the $\sim 40-\mathrm{kD}$ molecular mass is likely due to co-/post-translational modification of the protein. Indeed, in preliminary studies, we found HDGF to be both $N$ - and $O$-glycosilated (C. Hikita, J. Oliver, and Q. Al-Awqati, unpublished observations).

Whereas the antipeptide antibody recognized $\mathrm{a} \sim 40-\mathrm{kD}$ protein in immunoblots of homogenates of 7.1.1 cells and rat $\mathrm{E}_{15}$ kidneys, in the media conditioned with 7.1.1 cells, the HDGF antibody recognized the $\sim 40-\mathrm{kD}$ protein as well as a protein of an apparent molecular mass of $\sim 25 \mathrm{kD}$ and a less prominent protein of $\sim 35 \mathrm{kD}$. In the initial isolation of HDGF by Nakamura et al. (10), the protein obtained from media conditioned with hepatoma cells also had an apparent molecular mass of $\sim 25 \mathrm{kD}$. The smaller forms of HDGF could either be secreted forms of the intracellular protein (i.e., processed before secretion) or result from proteolysis after secretion. The second possibility is more likely because while both the $\sim 40-\mathrm{kD}$ form of HDGF as well as the smaller forms of the protein could be detected in media conditioned for $3 \mathrm{~d}$, only the $\sim 25$-kD protein (as well as the less prominent $\sim 35$ $\mathrm{kD})$ could be detected in media conditioned for $6 \mathrm{~d}$. Furthermore, 7.1.1 cells only contained the $\sim 40 \mathrm{kD}$ form of HDGF regardless of the time of incubation in serum-free media (not shown). We thus conclude that the $\sim 25-\mathrm{kD}$ form of HDGF is a fragment of the mature protein generated by extracellular proteolysis.

The cell growth assay we used during isolation of HDGF prevented the use of proteolytic inhibitors and proteolysis of the
B

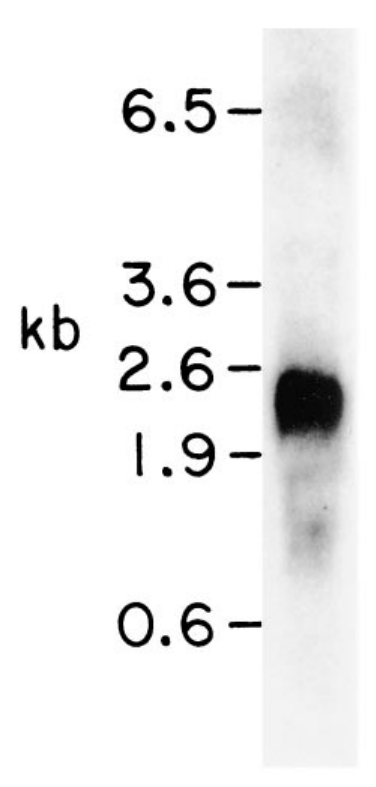

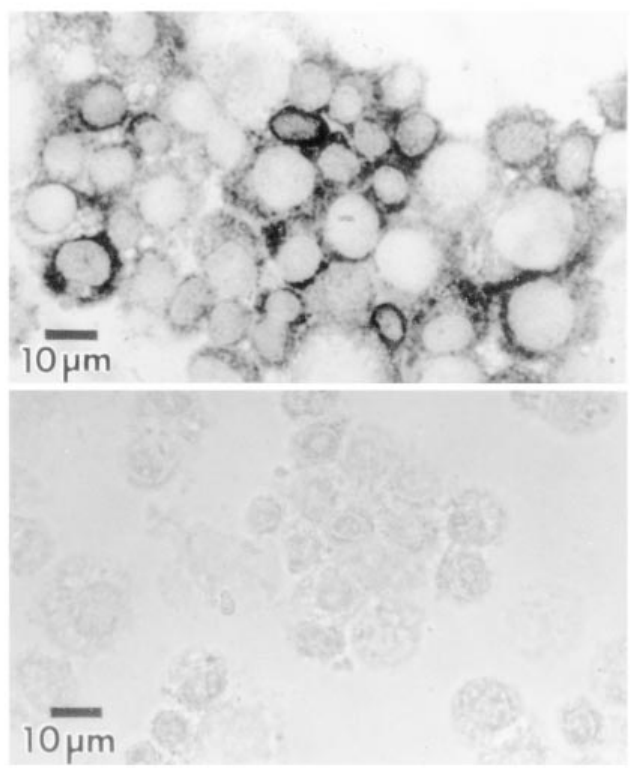

Figure 9. Detection of HDGF mRNA. (A) Northern blot analysis of 7.1.1 cells. $10 \mu \mathrm{g}$ of poly $\left(\mathrm{A}^{+}\right)$RNA from 7.1.1 cells were subjected to electrophoresis and transferred into a nylon filter. $(B)$ In situ hybridization of 7.1.1 cells with antisense riboprobe (top) and sense riboprobe (bottom). 


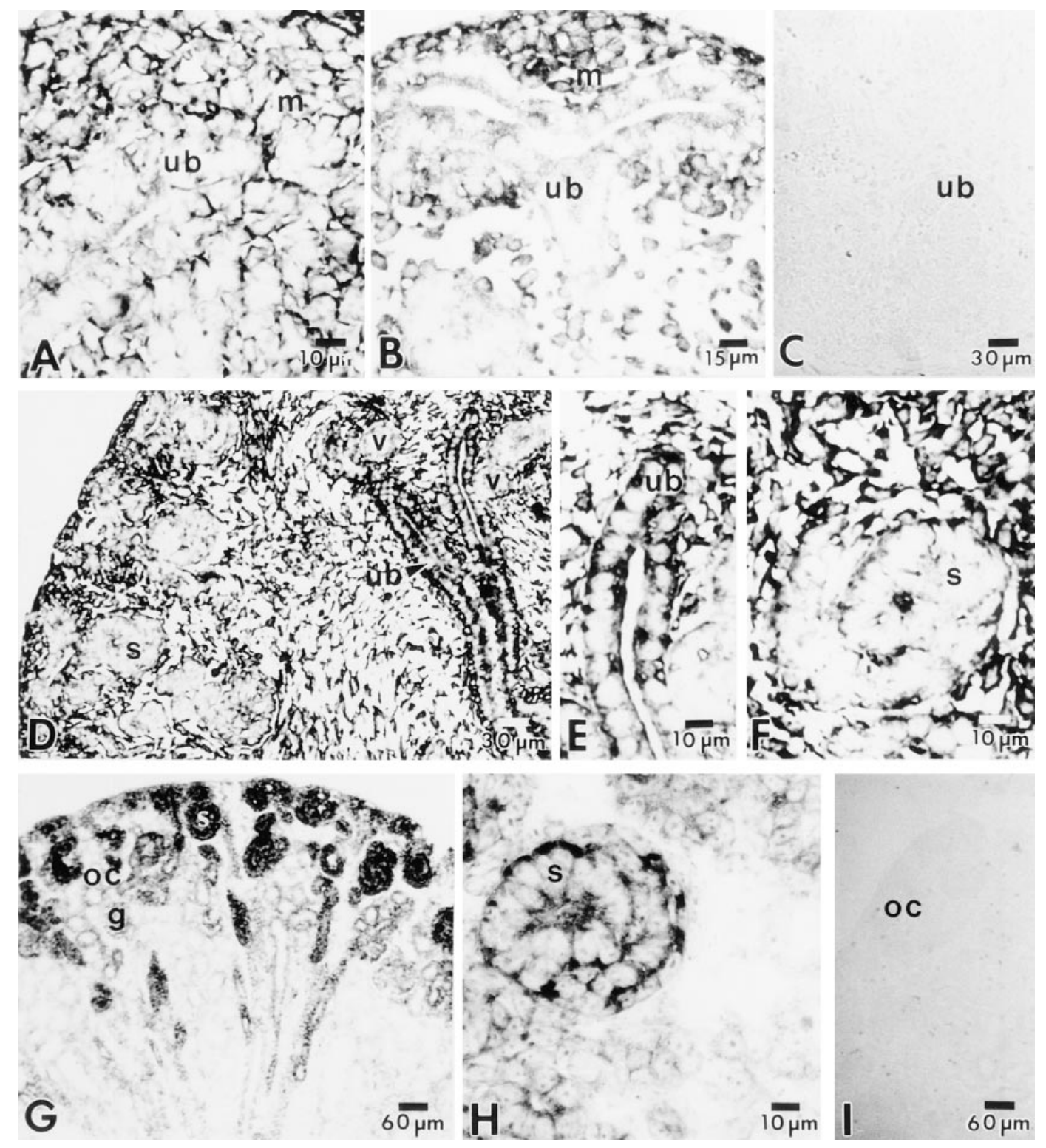

Figure 10. Localization of HDGF mRNA during kidney development. $(A)$ $\mathrm{E}_{13}$ renal anlage with ureteric bud $(u b)$ surrounded by the metanephrogenic mesenchyme $(m) .(B)$ $\mathrm{E}_{15}$ renal anlage with a branch of ureteric bud $(u b) .(C) \mathrm{E}_{15}$ renal anlage incubated with the sense riboprobe showing a branch of ureteric bud $(u b) .(D) \mathrm{E}_{17}$ kidney with the ureteric bud in its center $(u b)$ and many early $\mathrm{s}$ bodies $(s)$ in the periphery of the organ. $(E)$ Ureteric bud $(u b)$ cells of an $\mathrm{E}_{17}$ kidney. $(F)$ Early s body $(s)$ of an $\mathrm{E}_{17}$ kidney. $(G) \mathrm{E}_{19}$ kidney showing multiple s bodies $(s)$ and glomeruli $(g)$ in the outer cortex $(o c)$. (H) S body $(s)$ of an $\mathrm{E}_{19}$ kidney. (I) $\mathrm{E}_{19}$ kidney with outer cortex $(o c)$ incubated with the sense riboprobe. $(J)$ $\mathrm{E}_{21}$ kidney with multiple $\mathrm{s}$ bodies $(s)$ and glomeruli $(g)$. $(K)$ Two glomeruli $(g)$ and their respective parietal epithelial cells $(p e)$ in an $\mathrm{E}_{21}$ kidney. $(L)$ Kidney at 1 wk after birth with many glomeruli $(g)$ and ongoing development in the outer cortex (oc). $(M)$ Outer cortex of a 1-wk-old kidney; note the s body $(s) .(N)$ 1-wk-old kidney with outer cortex $(o c)$ incubated with the sense riboprobe. $(O)$ Adult kidney with multiple glomeruli $(g)$ and tubules. $(P)$ Glomerulus $(g)$ and a distal tubule $(d t)$ in the adult kidney. $(Q)$ Adult kidney section with one glomerulus $(g)$ and incubated with the sense riboprobe.

factor is the likely reason for our isolation of a $14-\mathrm{kD}$ fragment of it. Indeed, the findings with the Cos-7 cells expressing HDGF are consistent with this view. Media conditioned with Cos-7 cells transfected with HDGF cDNA contained the $\sim 40-\mathrm{kD}$ form of HDGF and a smaller $\sim 35-\mathrm{kD}$ form (present only in small amounts in the media conditioned with 7.1.1 cells; Fig. 3). However, after heparin-Sepharose chromatography, a new form with an apparent molecular mass of $\sim 14 \mathrm{kD}$ was detected (Fig. 4).

The data from immunoblots of $\mathrm{E}_{15}$ kidney homogenates, PCR of the rat $\mathrm{E}_{14}$ kidney cDNA library as well as immunohistochemistry and in situ hybridization of embryonic kidney sections all indicate that HDGF is present and synthesized in the developing kidney and that its location as well as its synthesis is highly regulated during renal ontogeny. Several lines of evidence suggest that HDGF has an important role as a growth factor in nephrogenesis and perhaps in the morphogenesis of the renal vasculature. First, HDGF is a growth factor. Though we isolated it after its endothelial growth activity, it is also effective in fibroblasts and some hepatoma cells (10) suggesting that like several other growth factors, it has some promiscuity in its effect, at least in cells in vitro. Needless to say, elucidation of HDGF-specific targets during renal ontogeny in vivo must await identification of its receptor and development of probes for its study, but the complex pattern of expression of HDGF mRNA suggests that HDGF may have a multifunctional role. Second, HDGF is synthesized by many cells of the developing kidney, and it is widely distributed through this organ, but except for some distal tubules, mRNA for HDGF disappeared from the kidney with completion of nephrogenesis. Third, mRNA for HDGF was highest during the most active period of nephron differentiation $\left(\mathrm{E}_{16-21}\right)$, and both HDGF and its mRNA were found in segments such as "s" bodies that develop into the proximal part of the nephron. This part of the 


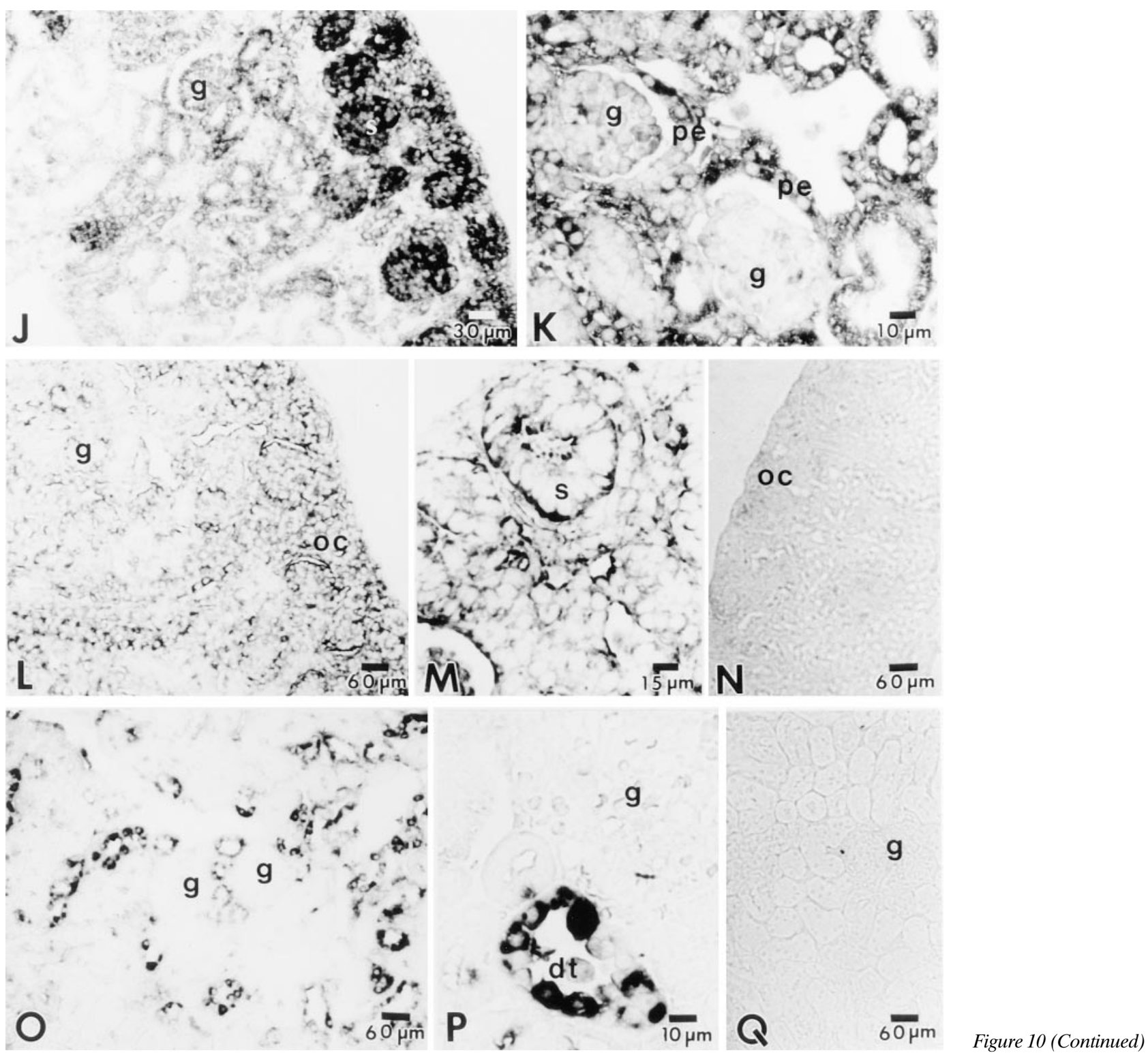

nephron is heavily vascularized with an intricate arrangement between capillaries and epithelial structures likely to require many mechanisms of control during its development. mRNA for the specific endothelial mitogen, VEGF is also found in "s" bodies (5). Platelet-derived growth factor, another potential endothelial mitogen has also been localized in comma and s-shaped bodies (17), but its sites of synthesis in developing kidney remain to be determined. Of note is that HDGF and its mRNA were present in the parietal glomerular epithelial cells of developing glomeruli and disappeared in mature glomeruli. This temporal location suggests that HDGF might act as a growth factor for the final development of the glomerular capillary loop.

In embryonic kidney mRNA for HDGF was frequently found in the same cells that contain immunoreactive protein. However, during the early stages of development $\left(\mathrm{E}_{13-15}\right)$ while the immunoreactive signal was quite prominent, the hybridization signal was weak suggesting that HDGF immunoreactive cells may accumulate protein from the circulation or that the half-life of the protein is longer. Similarly, proximal tubular cells in the adult kidney (with no detectable mRNA for HDGF) had vesicles with abundant HDGF. As many filtered proteins are endocytosed by these cells into vesicles, it is possible that the HDGF detected by the antibody in the proximal tubules may have originated in plasma.

HDGF has a $36 \%$ amino acid homology with the high mobility group 1 protein (HMG-1) and like this protein it lacks a signal peptide (10). HDGF has an internal hydrophobic region (located in peptide 1 of our isolate; Fig. 2) that could function as an internal signal sequence, but its mechanism of secretion is unknown. Interestingly, HMG-1 has been identified as amphoterin (18) a protein that increases neurite outgrowth (19) and appears to be involved in neural development $(19,20)$. HMG-1/amphoterin is located on cell surfaces and leading edges of neurons and other cell types suggesting that it plays a role in cell invasion $(19,21,22)$. As shown in Fig. 5, during early stages of kidney development, HDGF is also found in the periphery of metanephrogenic mesenchymal and ureteric bud cells suggesting a role for this factor in cell-to-cell interaction and cell movement. 


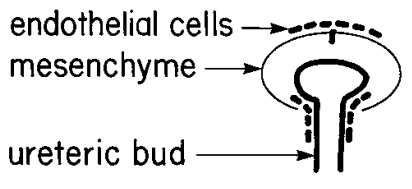

A

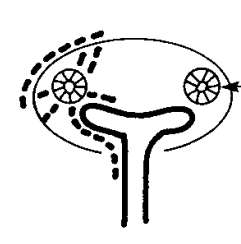

B
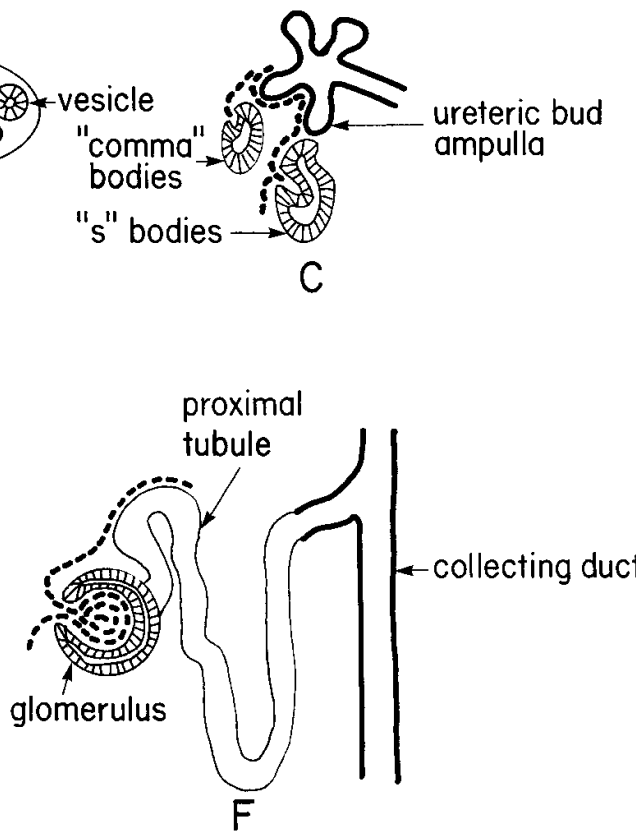

Figure 11. Scheme of rat kidney development. $(A)$ $\mathrm{E}_{12-14}$; renal anlage with endothelial cells invading it. (B) $\mathrm{E}_{13-19}$; renal anlage with mesenchymal to epithelial conversion with generation of epithelial condensates (vesicles) and endothelial proliferation. (C) $\mathrm{E}_{15}$ to development completion; ureteric bud branching and morphogenesis of comma and $s$ bodies with endothelial cells invasion of their crevice. $(D)$ and $(E) \mathrm{E}_{17}$ to development completion; nephron morphogenesis with glomerular capillary formation. $(F)$ Adult nephron. Dates are approximations as nephron development occurs in a centrifugal manner from the juxtaglomerular zone to the outer cortex.
In summary, HDGF is present and synthesized during kidney development in a synchronous manner with nephrogenesis. Whether the role of HDGF during kidney development is restricted to its action on endothelial cells or it has other targets requires identification of its receptor and location of it in embryonic kidney. As the receptor for HMG-1/amphoterin is a member of the immunoglobulin superfamily $(20,23)$, one of its members is a potential candidate for the receptor of HDGF. Its identification and location during kidney development will provide invaluable information on the role of HDGF in this process.

\section{Acknowledgments}

This work was supported by National Institute of Diabetes and Digestive Diseases Grant DK-46934.

\section{References}

1. Saxen, L. 1987. Organogenesis of the Kidney. Cambridge University Press, Cambridge. 173 pp.

2. Oliver, J.A., M.R. Goldberg, and Q. Al-Awqati. 1997. Endothelial cell targeting during renal development: use of monoclonal antibodies. Am. J. Physiol. 272:F153-F159.

3. Oelrichs, R.B., H.H. Ried, O. Bernard, A. Ziemiecki, and A.F. Wilks. 1993. NYK/FLK-1: a putative protein tyrosine kinase isolated from E10 embryonic neuroepithelium is expressed in endothelial cells of the developing embryo. Oncogene. 8:11-18.

4. Sariola, H., B. Peault, N. LeDouarin, C. Buck, F. Dieter-Lievre, and L. Saxen. 1984. Extracellular matrix and capillary ingrowth in interspecies chimeric kidneys. Cell. Different. 15:433-451.

5. Simon, M., H.J. Gröne, O. Jöhren, J. Kullmer, K.H. Plate, W. Risau, and E. Fuchs. 1995. Expression of vascular endothelial growth factor and its receptor in human renal ontogenesis and in adult kidney. Am. J. Physiol. 268:F240-F250.

6. Breier, G., U. Albrecht, S. Sterrer, and W. Risau. 1992. Expression of vascular endothelial growth factor during embryonic angiogenesis and endothelial cell differentiation. Development. 114:521-532.

7. Monacci, W.T., M.J. Merrill, and E.H. Oldfield. 1993. Expression of vascular permeability factor/vascular endothelial factor in normal rat tissues. Am. J. Physiol. 2624:C995-C1002.

8. Herzlinger, D., J. Barasch, C. Koseki, and Q. Al-Awqati. 1991. Immortal- ization of renal stem cells. J. Am. Soc. Nephrol. 2:438.

9. Sariola, H., P. Ekblom, E. Lehronen, and L. Saxen. 1983. Differentiation and vascularization of the metanephric kidney grafted on the chorioallantoic membrane. Dev. Biol. 96:427-435.

10. Nakamura, H., Y. Izomoto, H. Kambe, T. Kuroda, T. Mori, K. Kawamura, H. Yamamoto, and T. Kishimoto. 1994. Molecular cloning of complementary DNA for a novel human hepatoma-derived growth factor. J. Biol. Chem. 269:25143-25149.

11. Oliver, J.A. 1990. Adenylate cyclase and protein kinase C mediate opposite actions on endothelial junctions. J. Cell. Physiol. 45:530-548.

12. McGuire, P.G., and R.W. Orkin. 1987. Isolation of rat aortic endothelial cells by primary explant techniques and their phenotypic modulation by defined substrate. Lab. Invest. 57:94-105.

13. Hunter, W.M., and F.C. Greenwood. 1962. Preparation of iodine-131 labeled human growth hormone of high specific activity. Nature. 194:495-496.

14. Oliver, J.A. 1988. Canine angiotensinogen: purification and partial characterization. Hypertension. 11:21-27.

15. Harlow, E., and D. Lane. 1988. Antibodies. A Laboratory Manual. Cold Spring Harbor Laboratory Press, Cold Spring Harbor, NY. 726 pp.

16. Sambrook, J., E.F. Fritsch, and T. Maniatis. 1989. Extraction, purification and analysis of messenger RNA from eukaryotic cells. In Molecular Cloning, 2nd edition. Cold Spring Harbor Laboratory Press, Cold Spring Harbor, NY. 7.3-7.52.

17. Alpers, C.E., R.A. Seifert, K.L. Hudkins, P.J. Johnson, and D.F. Bowen-Pope. 1992. Developmental patterns of PDGF B-chain, PDGF-receptor and $\alpha$-actin expression in human glomerulogenesis. Kidney Int. 42:390-399.

18. Parkkinen, J., E. Raulo, J. Merenmies, R. Nolo, E.D. Kajander, M. Baumann, and H. Rauvala. 1993. Amphoterin, the $30 \mathrm{kDa}$ protein in a family of HMG1-type polypeptides. J. Biol. Chem. 268:19726-19738.

19. Rauvala, H., and R. Pihlaskari. 1987. Isolation and some characteristics of an adhesive factor of brain that enhances neurite outgrowth in central neurons. J. Biol. Chem. 262:16625-16635.

20. Hori, O., J. Brett, T. Slattery, R. Cao, J. Zhang, J.X. Chen, M. Nogashima, E.R. Lundh, S. Vijay, D. Nitecki, et al. 1995. The receptor for advanced glycation end products is a cellular binding for amphoterin. J. Biol. Chem. 270: 25752-25761.

21. Rauvala, H., J. Merenmies, R. Pihlaskari, M. Korkolainen, M.L. Huhtala, and P. Panula. 1988. The adhesive and neurite-promoting molecule p30: analysis of the amino-terminal sequence and production of antipeptide antibodies that detect p3- at the surface of neuroblastoma cells and brain neurons. $J$. Cell Biol. 107:2293-2305.

22. Merenmies, J., R. Pihlaskari, J. Laitiner, J. Wartiovaara, and H. Rauvala. 1991. 30-kDa heparin binding protein of brain (amphoterin) involved in neurite outgrowth. J. Biol. Chem. 255:16722-16729.

23. Neeper, M., A.M. Schmidt, J. Brett, S.D. Yan, F. Wang, Y.C. Pan, K. Elliston, D. Stern, and A. Shaw. 1992. Cloning and expression of a cell surface receptor for advanced glycosylation end products of proteins. J. Biol. Chem. 267: 14998-15004. 